\title{
Cultural rights versus human rights: A critical analysis of the trokosi practice in Ghana and the role of civil society
}

\author{
Joseph Yaw Asomah* \\ Department of Sociology, University of Manitoba, Canada
}

\begin{abstract}
Summary
In this article, I examine critically the culture versus human rights debate, and the crucial role and tactics of civil society organisations, drawing on insights from transnational advocacy networking, in the struggle to extend human rights to vulnerable people with reference to the trokosi practice in Ghana. This trokosi system turns virgin girls into slaves of the gods to atone for crimes committed by their family members. Theoretically, universal human rights must take precedence over any demand for cultural rights. In practice, however, the actual enforcement of human rights laws that conflict with other cultural values and practices can be more messy and complex than it is often conceptualised. Essentially, universal human rights accommodate, recognise and promote cultural rights; however, the latter ends at a point where its observance is likely to result in the violation of the fundamental human rights of others. I conclude that, although the call for cultural pluralism and the need to celebrate and respect the diversity of cultures sound legitimate, this demand cannot be allowed to trump the minimum package of the fundamental human rights that protect human dignity, wellbeing and integrity within the context of human rights protocols that state parties already have ratified. Yet, for this to materialise, stronger civil society organisations with a solid broad-based networking capacity and tenacity of purpose are crucial. This article helps to extend our current knowledge of human rights struggles and the implications these have for the furtherance of universal human rights.
\end{abstract}

Key words: universal human rights; cultural relativism; trokosi; civil society; transnational advocacy networking; Ghana

* BA (Ghana); asomahj@myumanitoba.ca 


\section{Introduction}

In December 1948, the ratification of the Universal Declaration of Human Rights (Universal Declaration) became a reality. In general, this human rights framework reflects a broader consensus and a monumental commitment of the international community to observe and guarantee a minimum package of fundamental human rights that must be enjoyed by everyone on the sole ground of being human. The central thrust of universal human rights is to protect human dignity and integrity from all manner of actions and practices - such as slavery, torture, oppression, tyranny, genocide - that are not only de-humanising, but also threatening to the survival and wellbeing of individuals, groups and humanity as a whole. Since its ratification, the universal human rights framework has provided the world with a powerful discourse and framework that legitimise struggles against violations of the fundamental human rights - political and civil rights, economic, social and cultural rights. ${ }^{1}$

In spite of the existence of this powerful framework, human rights violations continue to be witnessed in many forms and are of varying intensity. In particular, the rights of children, women and girls continue to be disproportionally violated with impunity. Evidence suggests that children spared war may still be vulnerable as they are confronted with extremely limited access to education, health care, welfare and food. Consequently, vulnerable young girls are subject to sex trade, sexual violence and abuse. There are over one million child prostitutes across the globe. It is estimated that there are 20000 under-age prostitutes in Thailand, 575000 in India, and 500000 in Brazil. ${ }^{2}$ Additionally, female mutilation and forced marriages at a young age continue to confront young girls. These occurrences culminate in shattering their future dreams of pursuing gainful careers. Clearly, the existence of the several international legal instruments guaranteeing the rights and protection of children appears to have had little utility in practice for many (women, girls and children), especially in developing countries, as their rights continue to be violated. ${ }^{3}$

While there are many factors accounting for this phenomenon, such as the struggle over economic resources, one of the most pressing issues affecting the rights of women and girls, in developing countries in particular, is the demand for cultural rights that conflict with the ethos of the universal human rights. Women's rights are often, but not exclusively, violated on cultural grounds. In the

$1 \quad$ MR Ishay The history of human rights laws: From ancient times to the globalisation era (2008).

$2 \quad$ Ishay (n 1 above) 302.

3 Y Eturk \& P Bandana 'Linking research, policy and action: A look at the work of the Special Rapporteur on Violence against Women' (2012) 60 Current Sociology 142-160. 
dominant patriarchal cultural context, universal human rights are labelled as a project of 'Western imperialism'. In effect, culture can be invoked to assert human rights and, at the same time, it can be deployed to rationalise the violation of the rights of others. A case in point is the trokosi system in Ghana. This is a cultural and religious practice that is observed not only in Ghana, but also in Benin and Nigeria. It is a practice where the vestal virgin girls are taken to shrines to serve the gods permanently as a form of 'reparation for crimes' committed by their family members. ${ }^{4}$ It is estimated that there are over 5000 victims of this cultural practice in Ghana alone, and 29000 to 35000 in the other remaining countries. ${ }^{5}$ These victims are 'generally overworked', overly subjected to sexual intercourse, and 'usually in poor health' due to the absence of medical facilities at the shrines. ${ }^{6}$

While the existing body of literature has enhanced our overall understanding of the trokosi system, a critical analysis of this traditional practice in the context of the culture versus human rights debate, with reference to the ethics of cultural preservation, is underexplored. Additionally, an analysis of the involvement of civil society and the tactics it deploys to ensure a balance between a cultural preservation and a respect for human rights has not been undertaken. The article intends to fill these research gaps, using the trokosi system in Ghana as a case study. This type of case study may, in turn, help to broaden our current understanding of this highlycontested terrain, the culture versus human rights debate, to inform human rights practice, observance, and advocacy. More specifically, the article addresses the following questions: Should universal human rights be rejected on the basis of cultural rights (or preservation) in reference to the trokosi system in Ghana? What role does civil society play in Ghana with regard to the trokosi system to free the victims? What tactics do civil society organisations in Ghana employ in their struggle to liberate the victims of the trokosi practice in Ghana, and what are the implications for human rights struggles?

\section{Universal human rights and cultural relativism}

The trokosi system is best analysed in the context of universal human rights and cultural relativism. Cultural relativism implies a respect for cultural differences and, therefore, calls for sensitivity to cultures other than one's own. It also draws attention to cultural pluralism, and the

4 EA Archampong 'Reconciliation of women's rights and cultural practices: Polygamy in Ghana' (2010) 36 Commonwealth Law Bulletin 325.

5 SC Aird 'Ghana's slaves to the gods' http://www.wcl.american.edu/hrbrief/v7i1/ ghana.htm (accessed 31 March 2014).

$6 \quad$ NA Bastine 'The role of the media in protecting women's and children's rights in democratic Ghana: Lensing the trokosi system in Ghana' (2012) 1 Africa Media and Democracy Journal 1. 
need to celebrate and respect this diversity of cultures. ${ }^{7}$ In the context of a human rights framework, proponents of cultural relativism argue that local cultures are capable of ensuring human dignity. In essence, the pro-cultural-relativist camp contends that the observance of universal human rights is 'intrusive and disruptive' to the deeply-held traditional mechanisms for the protection of lives, liberties, freedoms and security of people. ${ }^{8}$ This presupposes that human rights can be culturally specific. However, the assumption undergirding this argument appears to be flawed. The blatant violation of the human rights of people, particularly in the case of women and children in the global south, as evidenced by female sexual mutilation, the trokosi system, ${ }^{9}$ and so forth, weakens this claim. In this light, granting the demand for culturally-based human rights can to some extent be equated to the legitimisation of human rights abuses. As long as there must be a space for the expression of cultural uniqueness and identity, there must equally be a space for a minimum standard of guarantees to avoid the exercise of arbitrary discretionary powers, which tends to create room for abuse as a result of limited commonly-enforceable standards. If all cultures equally ensure the protection of the universal rights of people, then the existence of the universal human rights framework logically should not be a subject of controversy, given that it presupposes an existence of a shared objective of promoting human dignity. This shared vision should then be a unifying force, rather than a divisive one.

The second argument for cultural relativism is that it is ethically wrong and morally unjust to have a universal package of moral or legal standards that guarantees human freedoms and protection, because of the plurality and the context-specific nature of moral values and aspirations embedded in different cultures. ${ }^{10}$ This suggests that no particular set of moral codes is superior to another. For this reason, the universal human rights project is depicted as a 'cultural imperialism' from the west. Mutua, ${ }^{11}$ thus, argues that the universal human rights project is an attack on the very cultural fabric of the states regarded as inferior compared to Western standards. Thus, the human rights project is an orchestrated attempt, not only to 'civilise' the 'other', but also to ensure the wholesale embracement and practice of the liberal-multiparty democracy and capitalism that advance Western interests. Mutua is right to some extent, because it is erroneously assumed that the enjoyment of universal human rights

7 RA Wilson Human rights, culture and context: Anthropological perspectives (1997).

8 D Ayton-Shenker 'The challenge of human rights and cultural diversity' (1995) 2, http://www.un.org/rights/dpi1627e.htm (accessed 30 March 2014).

9 RK Ameh 'Reconciling human rights and traditional practices: The anti-trokosi campaign in Ghana' (2004) 19 Canadian Journal of Law and Society 51-72.

10 Ayton-Shenker (n 8 above).

11 M Mutua 'Savages, victims, and saviours: The metaphor of human rights' (2001) 42 Harvard International Law Journal 201-245. 
follows - almost automatically - upon the adoption of capitalism and multi-party liberal democracy.

Similarly, Mégret suggests that the pursuit of universal human rights is almost synonymous with the furtherance of political liberalism, such as the rule of law, good governance, and market capitalism. ${ }^{12}$ Therefore, there is a greater emphasis on cultural and political rights without equal emphasis on economic and social rights, such as the right to education, to health, to decent housing and to an adequate standard of living. In this regard, human rights may be viewed as an extension of the civilising mission that underpinned colonialism. Both Mégret and Mutua seem to argue that the human rights project is a smokescreen for a subtle strategy that expands Western imperialism and liberalism to advance Western interests. To some extent, their point is understandable because the embracement of Western culture, Western-style democracy, and capitalism is largely touted as a prerequisite for the enjoyment of human rights. This is not necessarily the case, as Megret and Mutua convincingly demonstrate.

However, the characterisation of the human rights project as an imposition of Western-originated ideology and philosophy to serve solely Western interests tends to distort the reality of human right abuses, and the utility of human rights projects in general. In particular, it downplays the gross violations of the rights of women and girls in many parts of the world, and the need to arrest the situation. In essence, universal human rights do not constitute a particular 'cultural standard', but 'rather one legal standard', which reflects a collective consensus of the international community, although law to some extent often reflects cultural values. Consequently, human rights cannot solely be ascribed to any particular religion or cultural orientation. ${ }^{13}$ The origin of human rights should not even matter so much if, indeed, they serve and advance the common good of humanity.

The demand for cultural preservation disproportionally hampers women's struggle for the full enjoyment of universal human rights. As Erturk argues, '[w]omen's human rights discourse and movements have become entangled within a culture-versus-rights dualism' ${ }^{14}$ This suggests that the demand for cultural rights may also constitute a smokescreen for serving the interests of patriarchal culture, a maledominated society that ensures the subordination and the oppression of women and girls. In addition, cultural relativism also overlooks the possibility for cultural dynamism as an essential characteristic of culture. This tendency is likely to stifle local cultures of the opportunities for needed social transformation. The quest for cultural

12 F Mégret 'Where does the critique of international human rights stand? An exploration in 18 vignettes' (2010) Faculty of Law, McGill University.

13 Ayton-Shenker (n 8 above) 2-3.

14 Y Erturk 'Culture versus rights dualism: A myth or a reality?' (2012) para $1 \mathrm{http}: / /$ www.opendemocracy.net/5050/yakin-erturk/culture-versus-rights-dualism-mythor-reality (accessed 20 March 2014). 
preservation should be assessed solely on the basis of its usefulness, not in the name of the wholesale preservation of cultural identity and traditions when, in fact, doing so would result in the erosion of the dignity, liberty, security and freedoms of others. This is underpinned by what Jeffers refers to as the 'ethics of cultural preservation'. ${ }^{15}$

From the lens of the universal human rights framework, cultural relativism should not be the foundation for the ongoing violation of the fundamental human rights of people. ${ }^{16}$ Universal human rights accommodate, recognise and promote cultural rights such as the 'protection of cultural heritage and the freedom of thought, conscience and religion' ${ }^{17}$ Nonetheless, this recognition of cultural rights ends at a point where the observance of cultural or religious practices is likely to result in the violation of the rights of others. International law outlaws the exercising of one's rights at the expense of the rights of others. Universal human rights are symbolic of the general will and commitment of the international community to respect and protect human dignity, which carries greater legitimacy, primacy and urgency than any cultural interest. In effect, human rights reflect a broader consensus with regard to human dignity than any particular culture. By implication, human rights should not be rejected on the sole basis of cultural norms, practices and values.

Granting the demand for culturally-based observance of human rights would potentially undermine and conflict with the spirit of the universal human rights framework. Culturally-specific human rights will, most likely, result in the creation of arbitrary discretions on the part of states. This in turn will create a vacuum for the weak enforcement of human rights laws as a result of differences in cultural norms and values, some of which are in stark conflict with the human rights framework. This possibility for abuse is clearly articulated by Ayton-Shenker, arguing: ${ }^{18}$

If cultural tradition alone governs state compliance with international standards, then widespread disregard, abuse and violation of human rights would be given legitimacy.

The reasons for the potential abuses are not far-fetched if culturallybased human rights were strictly the norm. First, some states will have an excuse for shirking their international human rights obligations on the ground of cultural relativism. Further, cultural ideals that conflict with human rights would be given primacy.

It is worth mentioning that I do not discount the importance of cultural relativism nor cultural rights in absolute terms in matters

15 C Jeffers 'The ethics and politics of cultural preservation' (2014) Workshop, University of Manitoba.

16 Erturk (n 14 above)

17 Ayton-Shenker ( $\mathrm{n} 8$ above); Deinayurveda.net 'Universal human rights and cultural relativism' (2011) http://www.deinayurveda.net/wordpress/2011/04/ saving-the-bedouin-heritage-and-biodiversity/? (accessed 21 October 2014).

18 Ayton-Shenker ( $\mathrm{n} 8$ above) para 9; Deinayurveda.net ( 17 above). 
relative to universal human rights. In fact, on the contrary, cultural relativism is particularly relevant in striking a balance between any claim to cultural rights and universal human rights. For instance, new emerging issues being framed as human rights discourses, such as same-sex marriages, are particularly worrying and contentious based on the differences in cultural values and orientations across the globe. Thankfully, cases brought before the European Court of Human Rights, where the complainants essentially pleaded with the Court to grant same-sex marriage as a human right, have not been upheld; article 12 of the European Convention on Human Rights that deals with marriage guarantees only marriage rights, or the right to marry, in conformity with national laws. ${ }^{19}$ This ruling demonstrates that universal human rights laws accommodate positive cultural values and heritage based on the respective national legal framework. The Court's decision reinforces the relevance of respecting cultural rights and cultural relativism within the bounds of national laws in general, and in the African context in particular, to help guarantee the sanctity of positive African cultural and religious beliefs, traditions and practices that are threatened by these new human rights movements. What this article suggests, however, is that in situations where states have ratified protocols on specific human rights issues, such as the right to human dignity, education, health and to choose a marriage partner, as enshrined, for instance, in the respective national constitutions, the African Charter on Human and Peoples' Rights (African Charter) and the Protocol to the African Charter on the Rights of Women (African Women's Protocol), any claim to cultural rights to the contrary should not be granted.

\section{African Charter on Human and Peoples' Rights}

Generally, African countries have re-affirmed their recognition of, and commitment to, promoting and safeguarding human rights in Africa; as exemplified in the African Charter, ${ }^{20}$ the African Charter on the Rights and Welfare of the Child (African Children's Charter) ${ }^{21}$ and the African Women's Protocol. ${ }^{22}$ The Women's Protocol notes that articles

19 S Doughty "Gay marriage is not a "human right": European ruling torpedoes coalition stance' (2012) http://www.dailymail.co.uk/news/article-2117920/Gaymarriage-human-right-European-ruling-torpedoes-Coalition-stance.html (accessed 13 June 2015); T Rokins 'Same-sex marriage and human rights' 27 March 2013 http://www.huffingtonpost.co.uk/tom-rokins/samesex-marriage-and-huma_b_254 9924.html (accessed 13 June 2015).

20 African Charter on Human and Peoples' Rights (1981) http://www.achpr.org/files/ instruments/achpr/banjul_charter.pdf (accessed 10 June 2015).

21 African Charter on the Rights and Welfare of the Child (1990) http:// www.achpr.org/files/instruments/child/achpr_instr_charterchild_eng.pdf (accessed 10 June 2015).

22 Protocol to The African Charter on Human and Peoples' Rights on the Rights of Women in Africa (2003) http://www.achpr.org/files/instruments/womenprotocol/ achpr_instr_proto_women_eng.pdf (accessed 10 June 2015). 
60 and 61 of the African Charter do recognise regional and international human rights instruments and African practices compatible with international norms regarding human and peoples' rights.

Specifically, on the issue of harmful cultural practices, article 5 of the African Women's Protocol states that '[s]tate parties shall prohibit and condemn all forms of harmful practices which negatively affect the human rights of women and which are contrary to recognised international standards'. Harmful practices, according to the Protocol, are defined as 'all behaviour, attitudes and/or practices which negatively affect the fundamental rights of women and girls, such as their right to life, health, dignity, education and physical integrity'. ${ }^{23}$ Based on this definition, I contend that the trokosi practice is clearly one of such harmful practices; therefore its continued observance is in contravention of this provision. The African Women's Protocol, therefore, demands of the signatories (the state parties) to take concrete steps, such as the enactment and enforcement of legislative instruments that prohibit this practice, to enforce this provision.

Additionally the African Children's Charter recognises in its Preamble that ${ }^{24}$

the child, due to the needs of his physical and mental development requires particular care with regard to health, physical, mental, moral and social development, and requires legal protection in conditions of freedom, dignity and security.

The Charter further states that the child - any person under the age of 18 - shall have the right to education and health services based on articles 11 and 14 respectively, while articles 15 and 16 of the Charter articulate protection against child labour, on the one hand, and child abuse and torture, on the other. In particular, article 21 of the Charter proffers protection against harmful social and cultural practices. The article states:

State parties to the present Charter shall take all appropriate measures to eliminate harmful social and cultural practices affecting the welfare, dignity, normal growth and development of the child and in particular: (a) those customs and practices prejudicial to the health or life of the child; and (b) those customs and practices discriminatory to the child on the grounds of sex or other status.

Invariably, the continuous adherence to the trokosi practice is in clear violation of these provisions. In fact, the African Charter accommodates positive African cultural values, morals, heritage, practices and customs that are not prejudicial to the health, life, and dignity of the African peoples, as articulated, for instance, in article $11(1)(c)$ of the African Children's Charter. ${ }^{25}$ Hence, I contend that a

23 Art 1(g) African Women's Protocol.

24 Art 1 African Children's Charter; PR Ghandi International human rights documents (2006) 443.

25 Art 11(1)(c) African Children's Charter. 
cultural practice, such as the trokosi practice, which is inconsistent with the African Charter and any international norms on human rights which this Charter recognises, should not be tolerated.

To help safeguard and promote the African Charter, the African Commission on Human and Peoples' Rights (African Commission) was established pursuant to article 30 of the African Charter. ${ }^{26}$ Further, based on article 45, the African Commission is mandated, among others, to investigate concerns relative to the promotion of human and peoples' rights in Africa, to prescribe remedial measures, and to co-operate with other African and international institutions involved in the promotion of human and peoples' rights. ${ }^{27}$ Similarly, the African Committee on the Rights and Welfare of the Child (African Children's Committee) is mandated to ensure that state parties safeguard and advance the fundamental rights and welfare of the African child, grounded in article 32 of the African Children's Charter. ${ }^{28}$ This demonstrates, at least theoretically, that signatories to the African Charter acknowledge the need to protect and advance the ideals of fundamental human rights, including the rights and welfare of the child. Nevertheless, the challenge is with enforcement in terms of taking practical steps to give effect to these general human rights protocols.

In sum, my discussion of universal human rights is within the context of human rights that the nation states already have ratified, presumably having taken into consideration their context-specific cultural rights. In this regard, my contention is that any claim to the exercise of any cultural right, as exemplified in the trokosi scenario, that is inconsistent with the furtherance of the fundamental human rights to which a particular state, in this case Ghana, is already a signatory, should not be entertained. In fact, failure to do this on the part of the state has the potential of opening up a floodgate of similar claims to cultural rights to preserve and strengthen harmful practices that are prejudicial to the health, dignity, freedom and security of innocent people, as symbolised in the case of the virgin girls who are being punished for crimes they never committed.

\section{The trokosi system in Ghana}

The trokosi system is an African traditional religious practice that exists in Ghana, Benin, Togo, and the Yorubaland in Nigeria. In Ghana, this cultural practice has been observed for several centuries among the Ewes of Tongu and Anlo in the Volta region, and the Dangmes of the

26 Art 30 African Charter.

27 Art 45 African Charter.

28 Art 32 African Children's Charter. 
greater Accra region. ${ }^{29}$ Trokosi means 'the slaves of the gods' ${ }^{30}$ Young virgin girls, usually between the ages of six and eight years, are sacrificed to the gods, as a form of reparation for the crimes committed by their relatives. ${ }^{31}$ For instance, Abla Kotor's family sent her, at the age of six, to the Awlo-Korti Shrine in Tefle (Volta region, Ghana) to atone for a crime which her father had committed (her father had raped his own niece). As Aird argues: ${ }^{32}$

Abla must now live and work for the local ... priests ... where she faces mental, physical, and sexual abuse, in hopes that by so doing, the gods will not bring vengeance upon the Kortor's family as retribution for the father's crime ... Denied access to education, prohibited from leaving, banished from family home ... Abla is just one of thousands of girls and women enslaved in this manner.

Abla's case sums up the nature of the trokosi practice that is based on the religious belief that crimes such as murder, incest, stealing and adultery are punishable by sending a virgin girl to the shrine of the gods. ${ }^{33}$ In effect, failure to do so is believed to trigger calamities such as death, diseases and economic hardship - by the gods on the families involved. The period of enslavement for the slave girls is a never-ending penance. Consequently, upon the death of a trokosi, the offending family is required to send another virgin girl to replace her. The priests, who are the custodians of the shrines of the gods, begin to have sexual intercourse with the girls as soon as they become teenagers. ${ }^{34}$ Further, the responsibility of caring for the children, the products of these sexual relationships, falls on the slave girls. In one instance, one priest fathered more than 400 children in his 37 years of priesthood. ${ }^{35}$

In general, Akpabli-Honu and Agbanu ${ }^{36}$ observe that four distinct categories of children are associated with the troxovi shrine in the Volta region of Ghana. They investigated primarily the freedom (if any) of these categories and concluded that the freedom of the trokosis, the primary focus of this article, has been curtailed on

29 Bastine (n 6 above).

$30 \mathrm{AB}$ Boaten 'The trokosi system in Ghana: Discrimination against women and children' in A Rwomire (ed)The African women and children: Crisis and response (2001) 91.

31 As above.

32 Aird (n 5 above) 1.

33 Bastine (n 6 above).

34 British Broadcasting Corporation 'Ghana's trapped slaves' http://news.bbc.co.uk/ 2/hi/programmes/from_our_own_correspondent/1158115.stm (accessed 20 March 2014).

35 Boaten (n 30 above) 94.

36 K Akpabli-Honu \& HK Agbanu 'Types and statuses of children of Troxovi shrines' (2014) 2 International Journal of Humanities and Social Studies 308-317. 
account of ritualistic reparation, confirming other studies ${ }^{37}$ that these victims are actually not free to live normal lives. Conversely, although the troviwo, one of the four categories that refer to the children born out of the chief priest's sexual relations with the trokosis, may benefit from formal education, as noted by Akpabli-Honu and Agbanu, most of them do not, the reason being that the chief priest, the proxy of the deity, often tends to have many children and this makes it practically impossible for him to sponsor all of them in school. To illustrate, Morklis ${ }^{38}$ reported that one chief priest in Tongu (Ghana) fathered 522 children with 76 wives and an unspecified number of concubines; Kugogbe ${ }^{39}$ reports similar findings. This situation is largely preventable if the trokosi victims were not in bondage that leads to 'forced' sexual relations with the chief priests, culminating in the birth of many children. Against this backdrop, International Needs Ghana (ING) has set up schools in the Tongu traditional area to help provide formal education for these children, as reported by AkpabliHonu and Agbanu. ${ }^{40}$

As noted earlier, the trokosi system is not recognised as a crime but rather a justice system that requires that a virgin girl be offered to serve and appease the gods for a crime (such as murder) committed by a family member. ${ }^{4}$ In this context, the practice of the trokosi justice system is believed to serve as a deterrence to ensure the prevention of crime in the trokosi jurisdiction, by way of warning people who intend committing a crime that they stand the risk of sacrificing their virgins to atone for such crime. What is problematic, though, with this assertion is that the wrongdoers get away with the crime they have committed, while the innocent virgin girls are punished and dehumanised as permanent slaves to the gods. This cultural practice reflects gender discrimination and serves the sole interest of the patriarchy. In this dominant patriarchal cultural context, the males are the authoritative figures, decision makers and custodians of the traditional practices; women often tend to have no say in traditional society, and this has facilitated the gross discrimination against them by their male superiors. ${ }^{42}$

The adherents of African traditional religion argue that the trokosi practice does not constitute any human rights violations. They maintain that universal human rights are 'foreign, imported values

37 Aird (n 5 above) 1; Amev (n 9 above); Bastine (n 6 above); DY Dzansi \& P Biga 'Trokosi - Slave of a fetish: An empirical study' (2014) 12 Stud Tribes Tribals 1-8 http://www.krepublishers.com/02-Journals/T\%20\&\%20T/T\%20\&\%20T-12-0-00014-Web/T\%20\&\%20T-12-1-000-14-ABST-PDF/S-T\&T-12-1-001-14-336-Dzansi-DY/S-T\&T-12-1-001-336-Dzansi-D-Y-Tx[1].pdf (accessed 10 June 2015).

38 AEO Morkli 'The tradition behind the trokosi system' in Avt Ac V (ed) (1995) 2 Progressive Utilisation Magazine 2-5.

39 SK Kufogbe 'National study on the trokosi practice in Ghana' (2008), research report presented to International Needs, Accra, Ghana.

40 Akpabli-Honu \& Agbanu (n 36 above).

41 As above.

42 As above. 
that contradict African traditional values' ${ }^{43}$ They further contend that the trokosi system is a key component of the African traditional religion and culture, which is endorsed by the Ghanaian Constitution through the provision on the freedom of religion as enshrined in article $21(1) .{ }^{44}$ For this reason, any attack on the trokosi is invariably an attack on freedom of religion and worship and, for that matter, is unconstitutional. At the same time, they fail to recognise the rights of the victims of the trokosi system as guaranteed by the same Constitution that they draw on to assert their right to freedom of religion. Article 12(2) of the 1992 Constitution of Ghana affirms the fundamental human rights and freedoms of every citizen. This provision demands that people must not exercise their rights and freedoms in a way that leads to the violation or infringement of the rights and freedoms of others, as illustrated by the trokosi practice. ${ }^{45}$

The violation of the universal human rights of the victims, as a result of the trokosi practice, takes many forms, such as enslavement, sexual exploitation and forced (child) labour. ${ }^{46}$ Articles 16(1) and 16(2) of the Constitution of Ghana stipulate that no person shall be held as a slave or be subject to servitude. Additionally, article 26(2) of the 1992 Ghanaian Constitution outlaws any customary practice that de-humanises or endangers the physical and mental wellbeing of any citizen. ${ }^{47}$ Accordingly, the trokosi practice violates these constitutional provisions that prohibit any form of slavery. Further, the trokosi practice places the victims at 'high risk of contracting sexuallytransmitted diseases (STDS), such as HIV/AIDS', because the priests who sleep with them have many sexual partners. ${ }^{48}$ Moreover, article 28(4) of the 1992 Constitution states that ' $\mathrm{n}$ ] o child shall be deprived by any other person of medical treatment, education, or any other social or economic benefit by religion or other beliefs' ${ }^{\prime}{ }^{49}$ The trokosi practice, therefore, denies victims access to education and medical treatment, and this further constitutes a violation of the Ghanaian Constitution. It also contravenes the United Nations Convention on the Rights of the Child, which provides for the right of the child to education and medical treatment. ${ }^{50}$ In 1998 Ghana amended a

43 Amev (n 9 above) 54

44 United Nations Population Fund Ghana 'Liberating slaves and changing minds: Starting at grassroots' https://www.unfpa.org/endingviolence/html/pdf/chapter ghana.pd (accessed 20 March 2014); The government of Ghana '1992 Constitution of the Republic of Ghana' http://www.ghana.gov.gh/index.php/consti tution/395-1992-constitution-of-the-republic-of-ghana (accessed 1 September 2014).

45 United Nations Population Fund Ghana (n 47 above).

46 Ameh (n 9 above).

47 Government of Ghana (n 44 above).

48 Bastine (n 6 above) 27.

49 Government of Ghana (n 44 above).

50 Boaten (n 30 above). 
section of its Criminal Code to criminalise all 'customary or ritual servitude', which targets the trokosi practice in particular. ${ }^{51}$

Admittedly, there are varying estimates of victims of the practice. For instance, Agodzo and Morkli report $20000 ;{ }^{52}$ Dovlo and Kufogbe report $4462 ;{ }^{53}$ while Nukunya and Kwafo put the estimate at $9000 .^{54}$ ING's estimate is about 5000 women and children, as reported by Kufogbe, ${ }^{55}$ and Kufogbe reports that the Democracy and Human Rights Reports of the US State Department put the estimate at $100 .^{56}$ While these estimates may be inaccurate, the fact that this practice has not been abolished completely, despite the passage of a trokosi law criminalising it in Ghana, is clearly not in contention, making it concerning as indicated by the 2015 report of the African Children's Committee. ${ }^{57}$

In sum, the fact that the trokosi practice is in contravention of the universal human rights of the victims and the Constitution of Ghana is not in dispute. The Constitution of Ghana, the African Charter, and particularly the African Children's Charter, the African Women's Protocol and international human rights laws and conventions require that universal human rights should take precedence over cultural rights to preserve the trokosi practice in this regard. This transition, however, does not take place automatically; otherwise the trokosi system would long have been a thing of the past in Ghana. This suggests the need for a stronger activism of civil society to exert pressure on states and society at large to respect, protect and guarantee the fundamental human rights of the vulnerable.

\section{Conceptual overview of civil society}

A growing body of research has documented the indispensable role of civil society in human rights struggles. ${ }^{58}$ In effect, civil society deals

51 Amev (n 9 above).

52 D Agodzo 'Liberty comes to trokosi captives' (1996) 1 Truth and Life 20-21; Morkli (n 38 above).

53 E Dovlo \& SK Kufogbe 'Baseline study of female ritual bondage in Ghana' (1997) unpublished research report, Accra, Ghana.

54 GK Nukunya \& SK Kwafo 'Report on the trokosi system in South Eastern Ghana' (1998) unpublished research report, Accra. Ghana.

55 Kufogbe (n 39 above) 1.

56 Kufogbe 2.

57 African Children's Committee 'Committee on the Rights of the Child examines the report of Ghana' (2015) http://www.ohchr.org/EN/NewsEvents/Pages/Display News.aspx?NewsID =15987\&LangID=E (accessed 10 June 2015).

58 OV Vieira \& AS Dupree 'Reflections on civil society and human rights' (2004) 1 Sur International Journal of Human Rights 47-65; K Tsuitui \& CM Wotipka 'Global civil society and international human rights' (2004) 83 Social Forces 587-620; MJ Magliano 'Civil society and the governability of migrations on the South American political agenda: The refuge in human rights' (2011) 20 Espacio Abierto 5-23; R Kunnemann, \& S Monsalve Suarez 'International human rights and governing land grabbing: A view from global civil society' (2013) 10 Globalisations 123-139. 
with the creation of the necessary 'conditions for validating and realising human rights', such as the promotion of rights discourse. ${ }^{59}$ It 'amplifies the voices of particular interests' and constitutes a 'natural advocate for devalued invisible groups' through publicising injustice, and 'protecting private spaces from the state and market incursions'. ${ }^{60}$ Civil society also intervenes and collaborates with legal and political systems to ensure social justice and progressive transformation. ${ }^{61}$

For the purposes of this article, I define civil society as any organisation that is not run by government, although it may receive funding from the state to enable it to function or run effectively. In this case, civil society includes non-governmental organisations (NGOs). I draw on the transnational advocacy network discussion of Keck and Sikkink, given that it is useful for analysing work done by NGOs at the national level. ${ }^{62} \mathrm{NGOs,} \mathrm{domestically} \mathrm{and} \mathrm{internationally,}$ constitute the nucleus of civil society and 'most advocacy networks, usually initiating actions and pressuring more powerful actors to take positions'. ${ }^{63}$ They help bring new ideas on board, timely generate and provide information and 'lobby for policy changes'.

In recent years, international networking has increasingly become a strategy that NGOs rely on to connect with like-minded counterparts in order to share information, skills, strategies, and resources for advancing their common interests. Networking is particularly useful for the 'less powerful Third World actors' as it 'provides access, leverage and information', as well as funding, which otherwise would be almost impossible to obtain if the local NGOs were working on their own. ${ }^{64}$ The unprecedented pace of globalisation has facilitated this networking through increased opportunities for domestic, regional and transnational contacts through cheaper air travel, new electronic and communication technologies - including the internet and the global web - that accelerate information flows within and among the local, the regional and the global levels.

NGOs creatively craft messages that significantly and positively transform public understanding of an issue to enable and guide relevant political action. This 'construction of cognitive frames' is central to the political strategies of the transnational networks that also adopt a number of tactics, including information politics, symbolic politics, leverage politics, and accountability politics. ${ }^{65}$ Information politics is the capacity to convey 'politically usable information quickly and credibly' to anywhere that it is most likely to

59 Vieira \& Dupree (n 61 above) 57.

60 Vieira \& Dupree 56.

61 Veira \& Dupree 57; Ishay (n 1 above).

62 ME Keck \& K Sikkink Transnational advocacy network in international and regional politics (1999).

63 Keck \& Sikkink (n 65 above) 92.

64 As above.

65 Keck \& Skikkink (n 65 above) 95. 
have the greatest effect. ${ }^{66}$ Fundamentally, it is about the ability to frame an issue to take on a new sense of urgency in a credible and legitimate manner that irresistibly and convincingly speaks to the major actors involved in a way that stimulates the greatest concerted action for redress. Leverage politics, basically, entails the capacity of NGOs to bring on board powerful actors who are more likely to influence a situation, while accountability politics essentially exert pressure on powerful actors to act on the promises and principles that they have officially ratified.

These insights from transnational advocacy network by Keck and Sikkink are particularly useful in examining the role and tactics used in the work performed in Ghana, which is at the national level, with respect to the struggle to free trokosi victims. This transnational advocacy network sheds light on the workings of the NGO called International Needs Ghana (ING) in its efforts to liberate the victims of the trokosi practice in Ghana. The operations of the ING in this liberation struggle will help contextualise the crucial role of civil society organisations, and the tactics it deploys in holding states accountable to respect, protect and guarantee, universal human rights, as required by international human rights law.

\section{Struggles for the abolishment of the trokosi system in Ghana}

The first attempt that focused on the abolition of the trokosi system occurred in 1923, when Daniel Nyagbledsi wrote two letters on different occasions to the Governor of the then Gold Coast (now Ghana), which was under British rule at the time. ${ }^{67}$ He demanded the abolishment of the trokosi system. The Governor directed the Secretary of Native Affairs to investigate the issue. The District Commissioner, who was tasked to investigate this issue, concluded that the practice did not constitute a crime as long as the people involved continued to pay their levy to the Colonial Administration.

In another development, the Fetish Slaves Liberation Movement (FESLM), headed by Mark Wisdom, a minister of a local church, waged a war to end the trokosi system in the 1970s and 1980s. FESLM was the first to use the modern Ghanaian media to draw public attention to the trokosi system; and it took a Christian-based and radical approach - taking the gospel directly to the shrines, with a view to delivering the trokosi priests from evil spirits, and freeing the trokosis for Christ. 68 This approach was perceived as disrespectful and culturally insensitive, which sparked strong opposition from the adherents of the African traditional religion, a group committed to

\footnotetext{
66 As above.

67 Ameh (n 9 above).
}

68 As above. 
promoting and preserving the African traditional religion and culture. In addition, Missions International (MI), a Christian NGO based in Canada, initiated and spearheaded a fresh battle (although the exact date when $\mathrm{Ml}$ started this campaign in Ghana is not clear) to end the slavery experiences of trokosi victims. It is, however, evident that $\mathrm{MI}$ was also unsuccessful, because it followed a similar path to FESLM led by Mark Wisdom.

However, what made the biggest difference is the role played by ING. ${ }^{69}$ ING was launched in 1984 as a member of the global Christian organisation, International Needs (IN). The overall objective of the organisation is to help Christians serve God and to contribute to the development of their communities through the alleviation of poverty, hunger, disease, illiteracy, idolatry, and primitive beliefs and practices. ING is part of International Needs in Canada, Australia, New Zealand, the United States and Britain, which financially support the Ghanaian branch that is run and staffed by Ghanaians.

In 1990, ING released a report about the existence of the trokosi practice. This report brought the world's attention to the trokosi system, and it did so with a new sense of urgency that globalised the campaign by drawing on its global networks. The practice then became a topic of national and international discussion, when it was proven that trokosi constituted modern slavery. As Greene argues, ' $[\mathrm{t}]$ he priests sexually and physically controlled the girls, restricted their movements and failed to compensate them for their labour'. ${ }^{70}$ This recognition of trokosi as a form of slavery sparked a long battle for the freedom for these slave wives of the gods.

ING spearheaded the strongest ever anti-trokosi campaign in the 1990s. It collaborated with a host of organisations, such as the Commission on Human Rights and Administrative Justice (CHRAG), the Ghana National Commission on Children (GNCC), the Ghana Law Reform Commission (GLRC), the National Council on Women and Development (NCWD), the National Commission on Culture (NGC), the National Council on Civic Education (NGCE), the Federation of Women Lawyers (FIDA), Equality Now, Anti-Slavery International, and United Nations agencies, including United Nations Population Fund, Ghana. ${ }^{71}$ Through the high networking and lobbying capability of ING through its powerful and influential global networks, the government of Ghana amended a section of its Criminal Code in 1998. This amendment criminalised all forms of 'customary or ritual servitude', including the trokosi system. ${ }^{72}$

Further, ING engaged in massive negotiations with all the shrines in Dangme that led to the first-ever mass release of 40 trokosis, the slaves

69 As above; Bastine (n 6 above).

70 SE Greene 'Modern trokosi and the 1807 abolition in Ghana: Connecting past and present' (2009) 66 The William and Mary Quarterly 959-974.

71 United Nations Population Fund Ghana (n 47 above).

72 Ameh (n 9 above). 
of the gods, in July 1996. By December 2001, a total of 2800 (59 per cent) of the known 4714 trokosis had been released in collaboration with other NGOs. ${ }^{73}$ In addition to their lobbying and networking ability, another distinctive feature of ING in their struggle towards emancipation of the trokosis was its dialogical and sensitive approach to the issue. ING approached the traditional leaders and shrine priests in a culturally-accepted manner, such as presenting drinks and gifts, and drinking water from their calabash, as their custom demands. This created an atmosphere of trust that paved the way for ING to be granted an audience that allowed for a dialogue. Unlike its predecessors, such as FESLM and Mission International, ING emphasised cultural sensitivity and abolished its original religious mission of taking the gospel to the shrines to save both the trokosis and shrine priests. Instead, it adopted a number of approaches, such as 'village to village lectures, seminars and focus group interactions with shrine owners, practitioners, and opinion leaders in practicing communities' ${ }^{74}$ Through those platforms, it emphasised the rights of the trokosis, such as freedom from sexual exploitation, freedom from forced labour, freedom to choose a marriage partner, the right to human dignity, the right to education and the right to health care, in a mutually respectful and trustful manner. ING demonstrates that a change from within the practising communities is more sustainable, through the education and the involvement of practising communities, than a change imposed from the outside.

ING also employs local people, who speak the same language and understand the culture and customs of the communities engaged in the trokosi practice, in the struggle for emancipation of the trokosis. Further, the ability of ING to connect with both local and like-minded international organisations played a major role in galvanising a concerted effort that pressurised the government of Ghana to criminalise the trokosi practice in $1998 .{ }^{75}$ Moreover, a coalition of several NGOs, the media and government departments and establishments also supported this human rights struggle of Daniel Nyagbledsi, FESLM and Mission International. ING demonstrates that human rights struggles that are broad-based and well-connected can achieve results. It is about getting 'politically usable information' timely to where it is more likely to have the greatest effect.

After the liberation of the trokosis, ING ran rehabilitative programmes for the victims. These programmes focused on dealing with the psychological damage caused to victims as a result of their captivity, helping the trokosis integrate into their communities, and helping them acquire formal education and vocational skills to be able to live independently. After these programmes, a follow-up was done to ensure that the victims are able to integrate into their communities. 
While rehabilitating the victims, ING continues to engage with the priests, community leaders, chiefs and the people as a whole to deepen awareness regarding human rights issues to prevent any possible future relapses into the trokosi practice. ${ }^{76}$

Despite these achievements, and the existence of many national and international laws and conventions - such as the Law Prohibiting Ritual Servitude, the Criminal Code, (Amendment) Act of 1998, (Act 544), the Criminal Offences Act, 1960, (Act 29), the Children's Act of 1988, and 1989 Convention on the Right of the Child - the trokosi system still has not disappeared completely. Generally, the laws have not been strictly enforced by the state, as there is no evidence of any arrest of the shrine priests or prosecution of any involved in the practice. The government of Ghana has offloaded its obligation to NGOs who work to eliminate the practice. In response to a question on the enforcement of the trokosi law by parliament in 2000, the Minister of Social Welfare suggested that education could be more effective than mere enforcement of the law. ${ }^{77}$ He also conceded that the NGOs were doing most of the work, given that they are more competent in handling the trokosi issue.

The Ghanaian government's reluctance regarding the enforcement of the trokosi law is not surprising. Evidence suggests that states are reluctant to advance human rights ideals. ${ }^{78}$ In reality, the state is both a custodian and a violator of human rights, and it is in this context that Ishay, for instance, calls for a stronger civil society to press for the realisation of human rights. ${ }^{79}$ Even when there is a political commitment to act, it is often difficult to influence the socio-cultural foundations of cultural and religious practices that conflict with universal human rights. This can further be compounded by the hostile and unco-operative stance of some bureaucrats and public officials who may frustrate government policies and laws to stamp out these practices, as observed by $\mathrm{An}-\mathrm{Na}^{\prime} \mathrm{im} .{ }^{80}$ Thus, changing religious and customary laws to reflect international human rights laws does not necessarily guarantee the full implementation and realisation of the objectives of such laws, as exemplified by the trokosi system in Ghana. Often, such transformation, however, has to be pressed for peacefully, particularly by civil society.

Regarding the numbers of current non-liberated trokosi victims, it is extremely difficult to state the precise figure, as the practice might have gone underground, perhaps due to the passage of the trokosi law that prohibits it in Ghana. Despite the difficulty in estimating the figure, some scholars suggest that the number of non-liberated trokosi

Ameh (n 9 above).

As above.

Ishay (n 1 above).

As above.

80 AH An-Na'im 'State responsibility under international human rights law to change religious and customary laws' in R Cook (ed) Human rights of women: National and international perspectives (1992). 
victims may still be high, ${ }^{81}$ while others suggest that the practice seems to be on the decline. ${ }^{82}$ The fact that this traditional practice has not been eradicated does not suggest that ING, the most active anti-trokosi movement, has failed completely in its campaign to address the issue. In fact, on the contrary, ING has achieved significant success in comparison to similar anti-trokosi movements, as discussed. For instance, Dzansi \& Biga ${ }^{83}$ report that all their interviewees who were former trokosi victims mentioned ING as the driving force behind their liberation, while Amev ${ }^{84}$ reports the ground-breaking achievements of ING compared to other anti-trokosi movements. In light of the fact that the trokosi practice has not died down completely, despite the remarkable efforts of ING, suggests that working to get rid of a harmful cultural practice that is entrenched deeply and valued widely among the practising communities demands long-term commitment and investment.

\section{Conclusion}

Although there are varying accounts of the actual number or the estimates of the trokosis, as reported by Akpabli-Honu and Agbanu, ${ }^{85}$ these inconsistencies or contestations, however, do not make the truth about the continuous practice and the human rights concerns of the trokosi system go away. The fact that this traditional practice is still in existence, despite the enactment of the trokosi law that prohibits it in Ghana, is concerning, as noted recently by the African Children's Committee. ${ }^{86}$ This means that innocent virgin girls may still be subject to this practice should any member of their families commit a crime that warrants such sacrifices to the gods. For this reason, there is a need for continuous and sustained co-ordinated interventions to eradicate it.

The demand for the preservation of the trokosi practice, in the name of cultural relativism and freedom of religion, violates the basic human rights of the victims, as exemplified within the framework of the Constitution of Ghana, the African Charter, the African Women's Protocol, the African Children's Charter and recognised universal human rights laws and conventions which the state parties, including Ghana, have ratified. Essentially, it is in this context that it is contended that, although the call for cultural pluralism and the need to celebrate and respect the diversity of cultures sound legitimate, these demands should not be allowed to trump the minimum package of human rights which state parties have ratified to protect

81 Aird (n 5 above).

82 Dzansi \& Biga (n 37 above).

83 As above.

84 Ameh (n 9 above).

85 Akpabli-Honu \& Agbanu (n 36 above).

86 African Children's Committee (n 57 above). 
human dignity and the wellbeing and integrity of the citizenry. Also, culture is dynamic and should ideally be open to new possibilities for social transformation; conceivably, culture can be preserved if doing so will not necessarily lead to the infringement of the basic fundamental human rights of others, as the trokosi practice clearly illustrates.

By helping to liberate most of the trokosi victims, compared to other anti-trokosi movements, ING has demonstrated that the role of civil society is indispensable in the struggle for human rights among marginalised and vulnerable people. This is critical as the nation state, itself, is both a guardian and violator of human rights in many respects, including the lack of a strong political will to enforce human rights laws, often based on political expediency, particularly in countries like Ghana. Civil society needs to be strong and have tenacity of purpose and culturally-acceptable and sensitive strategies to address major fundamental human rights concerns, including harmful cultural practices. Also, human rights struggles demand an appropriate and creative blend of tactics, including information politics, leverage politics, symbolic politics and accountability politics, as reflected in the operations of ING. Further, the role of the parent International Needs and its affiliates added a unique dimension to the struggle by way of financial assistance, material support and networking. This suggests that a lot of resources, skills and commitments are needed if we are to succeed in extending universal human rights to vulnerable people across the globe.

Individuals, groups and organisations committed to eradicating harmful cultural practices can learn a number of lessons from the operations of ING. First, there is a need to demonstrate a strong cultural sensitivity, particularly in terms of approaching the powers that be in practising communities, as emblematised in ING's offering of gifts and drinks and their willingness to drink water from the calabash, as the custom demands, to build excellent rapport, mutual trust and respect to pave the way for meaningful critical dialogue to begin. Second, the development of a strong networking capacity to bring on board all parties that have a stake in the practice and whose ideas, power and influence can impact positively on the outcomes of the movement cannot be overlooked. Third, there must be ongoing education to create public awareness about the repercussions and human rights concerns of the harmful cultural practices in question, in particular educating, dialoguing and negotiating with the custodians, such as community leaders, priests and chiefs, on the human rights implications of these cultural practices to preclude future violations. Fourth, the use of local people to spearhead the movement to capitalise on their insider's knowledge and to localise the movement to dispel notions of cultural imperialism is worthwhile. The policy of parent International Needs that allows local people to spearhead the human rights struggle and run the organisation in Ghana highlights the fact that the local people have the answer to their problems. This suggests that a bottom-up approach is often more effective than a 
top-down one. Fifth, designing appropriate interventions, such as providing seed capital and employment skills, to facilitate an effective integration of the liberated trokosi victims into society, is particularly important to enable them to live independently. Sixth, learning from the mistakes of similar movements is useful to design workable strategies to confront the problem. Lastly, there is a need for the continuous monitoring and evaluation of the approaches of the movement to take corrective measures when necessary.

Apart from these lessons drawn from the operations of ING, it is recommended that ING and similar movements in Africa step up their engagement with relevant human rights institutions, especially the African Children's Committee, to hold the signatories to the African Charter to account in enforcing human rights norms. Finally, state parties to the African Charter ought to take practical measures to enforce these provisions. As strict prosecution of the adherents of harmful cultural practices can drive it underground, efforts should be made to engage with practising communities, especially the chief priests, in building a broad-based consensus on the best way forward to address the problem holistically.

It is also worth noting that the overall intent of the trokosi practice is positive in the broader context of social and crime control in serving as a deterrent to future offenders that they stand the risk of sacrificing their beloved virgin girls to the gods. Conversely, the problem, however, is with the mechanisms in place to achieve this intent that take the form of lifetime imprisonment of innocent virgin girls who have not committed the crimes for which they have been imprisoned; in any case, the perpetrators could be held directly responsible for their actions. These innocent virgin girls should be given the chance to live normal lives; they should not be subject to punishment for crimes that they never committed in person. Finally, in light of the inconsistencies of the estimates of the trokosis, further empirical studies are suggested to put the records straight and to offer pragmatic policy prescriptions to help stamp out this practice. 